\title{
Tribute - and a clinical lesson in bioethics and quality of life
}

\author{
C Crisci Salvatore Maugeri Foundation, Campoli, Italy
}

\begin{abstract}
This is a tribute to a patient whose strength and love for life demonstrate that quality of life has a very personal value.
\end{abstract}

Central neurofibromatosis (NF-2) was a curious and interesting problem to me as a neurologist, when I met Louise, so I attempted a "very scientific" approach, already savouring the chance of a good clinical paper to publish. But her clinical history sounded more like a Gothic tale of a relentless curse than a family anamnesis, and at the end of her story it was impossible to me to remain professionally cool, or to consider her just "an interesting clinical case".

She was one of seven: five boys and two girls whose mother died at 37 from a cerebral "problem". The eldest was Mary; she had become deaf and blind before dying at 21 in "status epilepticus". Then came George, killed at 19 by a car while trying to cross a street: he was almost blind, deaf and ataxic. Cyrus had a neurosurgical intervention at 15 to ablate a glioma, and never woke up from anaesthesia. The fourth, Charles drowned at 16, when he understood that his eye problems were the onset of his family curse. Vincent, 31 years old, is waiting his turn: the illness may have spared his brain, but not his mind. He will never have a normal life, spending his time searching for the first signs of the illness that has destroyed his family. Only Luke, the youngest, at 22 , was healthy and still hopeful.

Louise was 26 when she came into my division: a

\section{Key words}

Neurofibromatosis; living will; bioethics. wonderful woman, almost blind and severely ataxic, with a desperate husband and two lovely children. Along with Luke we talked, laughed and suffered $\underset{\omega}{N}$ together, trying in any way to stop, to exorcise the enemy growing in Louise's head. After three surgical $\vec{\infty}$ brain procedures, we knew we had lost the battle. 오 She spent the last two years in bed, blind, almost deaf and severely paralysed, assisted by Luke. Her $T$ husband had not been able to bear the pain, and had abandoned her. Her smile, her love of life, little everyday things taught me that no test, questionnaire or guideline can measure the quality of life. Louise never talked of dying ". . . life is marvellous even in hospital bed ..." she said, "even when the on things one can still experience are the taste of a gode coffee or the perfume of the nurse compassionate cleaning one's miserable body". She had never heard of bioethics and did not know the meaning of the word "euthanasia", but she taught me more than I have learned from any book or debate about the meaning of living will and love for life. As I am an atheist and Louise was religious, we avoided the religious issue in our talks: time was too precious to her to spend it in philosophical discussions. I never asked her how she could believe in a God who $\frac{}{0}$ played with her and her family this way, because I already knew the answer, absurd to me : “. . . blessed $\delta$ are they who suffer, for they will be comforted ..." (Matthew, 5:4). I could not accept this way of $ᄋ$ thinking and probably I never will, but when I think of Louise, I envy her her "absurd" faith and moral strength, her hunger of life.

Claudio Crisci, MD, is a Neurologist and a Physician. $\mathrm{He}$ is Chief of the Department of Neurological $\mathrm{N}$ Rehabilitation at the Salvatore Maugeri Foundation, Campoli, Italy. 